\title{
Aid effectiveness: when aid spurs investment
}

\author{
Felicitas Nowak-Lehmann \\ Department of Economics, University of Goettingen, Goettingen, Germany, and \\ Elena Gross \\ Department of Economics, University of Bayreuth Institute of African Studies, \\ Bayreuth, Germany
}

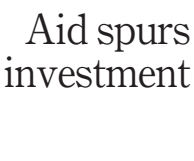

189

Received 17 August 2020

Revised 8 January 2021 6 March 2021

Accepted 14 March 2021

\begin{abstract}
Purpose - This paper aims to analyze the effectiveness of aid in stimulating investment using different measures of aid and up-to-date panel time-series techniques. This study controls for endogeneity by using dynamic ordinary least squares (DOLS) and minimizes the risk of running a spurious long-run relationship by using series that are cointegrated. This paper finds evidence that aid promotes investment in countries with good institutional quality and gain interesting insights on the influence of country characteristics and the amount of aid received. Aid is ineffective in countries with unfavorable country characteristics such as a colonial past, being landlocked and with large distances to markets. Aid can boost investment in regions that receive high (above-median) amounts of aid such as Africa and the Middle East but not in regions that receive low amounts of aid. Investment-targeted aid is effective but non-investment-related aid can also enhance investment.
\end{abstract}

Design/methodology/approach - Regressions on the aid-investment nexus are based on either a rather simple (115 countries) or an extended/augmented investment model (91 countries). The data covers the period of 1973-2011 and 1985-2011 if the institutional quality is included. This study estimates the relationship between aid and investment by applying the DOLS/dynamic feasible generalized least squares technique which is based on a long-run relationship of the regression variables (cointegration). In this framework, this paper incorporates country-fixed effects, control for endogeneity, autocorrelation and take heteroscedasticity and cross-country correlation of the residuals into account.

Findings - This study finds empirical evidence that aid promotes investment in countries with good institutional quality and gain interesting insights on the role played by country characteristics and the amount of aid received. Aid is ineffective in countries with unfavorable country characteristics such as the colonial past, being landlocked, distant from markets. Aid can boost investment in regions that receive high (above-median) amounts of aid such as Africa and the Middle East. Investment-targeted aid is effective but non-investment-related aid also able to enhance investment.

Research limitations/implications - The study looks at the investment to gross domestic product (GDP) ratio (including domestic investment and foreign direct investment (FDI)) and, hence does not disentangle these factors. It looks at the net effect (positive and negative impact together) and, therefore does not allow to identify the direct crowding out the impact of aid. Of course, if this paper finds that aid has a negative impact on investment, it is clear that aid must have crowded out either domestic investment or FDI or both.

Practical implications - The authors think that it is relevant to have identified the circumstances and settings in which foreign aid can be particularly effective and in which foreign aid needs accompanying

(C) Felicitas Nowak-Lehmann and Elena Gross. Published in Applied Economic Analysis. Published by Emerald Publishing Limited. This article is published under the Creative Commons Attribution (CC BY 4.0) licence. Anyone may reproduce, distribute, translate and create derivative works of this article (for both commercial and non-commercial purposes), subject to full attribution to the original publication and authors. The full terms of this licence maybe seen at http://creativecommons.org/ licences/by/4.0/legalcode



Applied Economic Analysis Vol. 29 No. 87, 2021 pp. $189-207$ pp. 189-207
Emerald Publishing Limited 2632-7627 
measures that improve the effectiveness of aid. Also, it is relevant that the relative amount of aid received (aidto-GDP ratio) must be quite high so that aid can increase investment.

Social implications - This study sees that the least developed, low-income countries and (in terms of regions) the sub-Saharan Africa countries benefit from aid. This is very desirable. This paper further sees that higher relative amounts of aid do help more and that it is helpful to care about a better institutional quality in developing countries. Hence, this study provides some support for the desirability of aid.

Originality/value - The paper was done very diligently, and this study is very confident that the results are robust. This paper is also confident that this study has studied the long-run (which is of special importance) nexus between aid and investment. The estimation technique used is original, as it combines regular DOLS with corrections for autocorrelation and cross-section dependence.

Keywords Aid effectiveness, Dynamic ordinary least squares (DOLS) panel regressions, Impact on investment, Types of aid

Paper type Research paper

\section{Introduction}

In recent decades, the improvement of aid effectiveness has been a priority for development agencies, which has led to a dramatic increase in the number of studies on aid effectiveness and its impact on growth. Research from the past 40 years suggests that development aid influences economic growth in a small but positive and statistically significant way. Mekasha and Tarp (2013) support the hypothesis of a positive impact of aid on growth.

However, there are still open questions concerning the growth-generating and growthdeterring impact of aid. A functioning aid-investment channel is critical, as the aidproductivity, aid-domestic savings and aid-real exchange rate transmission channels can counteract growth. Empirical evidence suggests that aid significantly reduces productivity (Alvi and Senbeta, 2012), significantly lowers domestic savings (Bowles, 1987) and leads to a significant appreciation of the real exchange rate that impedes growth by suppressing the export and the import substitution sectors of an economy (Rajan and Subramanian, 2011).

The aid-investment link requires further empirical analysis to identify the drivers of investment (such as domestic savings, foreign savings in the form of international loans, macroeconomic conditions, institutional quality, risk and aid) and the specific role of aid in enhancing investment. In an environment of low domestic saving rates, foreign aid can help bridge the saving-investment gap in form of external savings. Aid is especially crucial in the most disadvantaged developing countries that neither attract large amounts of international portfolio investment nor international loans (Lucas, 1990). Most importantly, foreign direct investment (FDI) is also insufficient in these countries, as, according to theory, unfavorable macroeconomic and institutional factors - e.g. high-interest rates, high risk, high volatility, low trade openness and poor institutional quality, etc. - influence investment decisions of foreign investors and can discourage FDI, which is part of domestic investment.

While boosting investment is clearly not the only objective of aid, it is an important instrument for breaking the vicious circle of underdevelopment (Solow, 1956; Swan, 1956; Romer, 1986). Depending on the theory of growth, investment is crucial not only to achieve higher short-to-medium-run growth (Solow's growth model) but also to achieve long-term growth (endogenous growth models). Levine and Renelt (1992) have identified investment as a robust driver of growth in cross-country growth regressions.

In the empirical literature on the aid-investment link, a variety of arguments have been cited to support either a positive (Donaubauer et al., 2016; Garriga and Phillips, 2014; Arazmuradov, 2012) or a negative (Boone, 1996; Herzer and Grimm, 2012; Selaya and Rytter Sunesen, 2012) impact of foreign aid on investment. 
The contribution of this paper is to complement previous analyzes of the aid-investment nexus with novel econometric methods that deal with relevant econometric issues (spuriousness, endogeneity, omitted variables), intending to find non-spurious, unbiased and robust estimates of the actual size of the aid coefficients. To pay tribute to the economic relevance of aid and other determinants of investment (measured as gross capital formation as a share of gross domestic product (GDP)), we evaluate the economic importance of the effect of aid on investment for different country groups and in different environmental settings. To complete the analysis, we also assess the impact of different types of development aid (classified by donor, financing instrument and sector) on investment bearing in mind that aid is targeted at investment to varying degrees. The estimations of this study are based on a sample of 91 to 115 countries covering the period 1973-2011.

To summarize, we find, on average, a positive and significant impact of aid on investment. This finding holds in particular for sub-samples of developing countries such as Africa and the Middle East. All previously listed country agglomerations receive not only above-median (more than $2 \%$ ) but also above-average (more than 3.8\%) amounts of aid (in terms of the aid-to-recipient GDP ratio). However, this finding does not hold for Asia and Latin America where the amount of aid received is below the median. In addition, the impact of aid is found to depend on unchangeable (time-invariant) circumstances such as being a small island, being landlocked, having large distances to markets and historical past, etc. Moreover, empirics show that aid is not effective in countries with the above-mentioned unfavorable time-invariant country characteristics. We find aid to spur investment in countries that obtain relatively substantial amounts of aid and in countries with good institutional quality. An additional finding is that both purely investment-related aid and non-investment-related aid are able to increase investment. An exception is an aid targeted to improve institutions, which does not enhance investment.

The rest of the paper is structured as follows: In Section 2, we present a literature review on aid effectiveness and identify research gaps. In Section 3, we model the aid-investment relationship and explain our econometric estimation strategy. In Section 4, we address the most important conceptual issues when modeling the aid-investment. Finally, Section 5 concludes.

\section{Literature review and research gaps}

Aid effectiveness has been studied quite intensively in recent decades but some key issues still require clarification:

- which type of aid is most effective;

- the circumstances (macroeconomic, political, institutional, inherited conditions) under which aid is most effective; and

- whether there is a minimum amount of aid necessary to be effective and promote development.

The majority of researchers have investigated aid effectiveness either at the macro or micro level and the empirical evidence, also known as the micro-macro paradox, has been rich in contrast. While the micro-evidence has leaned toward a positive effect of aid, the macroevidence has been less clear-cut and has remained more subject to controversy.

From a theoretical perspective, aid should have a positive and significant impact on investment and have a positive overall effect on economic growth. However, whether aid has a positive impact on investment and the extent of its effect is fiercely debated. Two metaanalyzes showed that aid has a positive impact on investment (Hansen and Tarp, 2000; 
AEA

29,87

Doucouliagos and Paldam, 2006), while Herzer and Grimm (2012) find a negative and significant impact of aid on private investment in a panel data study. Arazmuradov (2012), Garriga and Phillips (2014) and Donaubauer et al. (2016) study the impact of foreign aid on FDI and show that aid or at least specific types of aid such as aid for economic infrastructure, increase FDI. In contrast, Selaya and Rytter Sunesen (2012) find that the effect of aid is ambiguous, there is a positive impact when invested in human capital and public infrastructure but aid can crowd out private investment.

Other important transmission channels of aid on economic growth at the macro level relate to:

- the impact of aid on domestic savings (empirical studies find a negative and significant effect of aid, and hence, a negative effect on growth);

- the impact of aid on the real exchange rate (empirical studies show a negative growth effect via a real appreciation of the exchange rate);

- the impact of aid on total factor productivity (TFP) (empirical evidence finds that aid decreases TFP) (Alvi and Senbeta, 2012); and

- These transmission channels have been investigated by others and lie beyond the scope of this study (Gomanee et al., 2005).

As the literature on aid effectiveness has grown, researchers have started to group them into different generations of studies (Hansen and Tarp, 2000; Arndt et al., 2010, 2016; Mekasha and Tarp, 2013). The earlier studies (first generation) investigate the link between aid and domestic savings to finance investment and focus on foreign aid as part of external savings as a complement to domestic savings. These studies are based on the theoretical models of Rosenstein-Rodan and Chenery and Strout who identify structural disequilibria as a source of underdevelopment and argue in favor of planning economic development to overcome these structural deficits through high levels of investment spending. Rosenstein-Rodan (1961) emphasizes that underdeveloped countries require a big push, i.e. large amounts of investments, to embark on the path of economic development from their present state of backwardness. Chenery and Strout (1966) view foreign aid as a means to reach a certain output target by filling two gaps (the investment-savings gap and the trade gap). They used this two-gap model to compute the amount of foreign aid that is necessary to promote development. However, the simplistic view that foreign aid adds to the availability of external resources without substituting domestic savings has been challenged in empirical studies that show that foreign aid reduces the incentive to save in aid-receiving countries (Weisskopf, 1972).

The second generation of aid effectiveness studies focuses on the aid-investment link. These studies mostly build on the Harrod-Domar model. Investment and the productivity of capital, which is considered constant, determine output growth. In this model, all savings and aid as foreign savings are used to finance investment.

Empirical studies show that aid can increase total savings but not by as much as the aid flow, suggesting that a considerable part of the aid is consumed rather than invested [1] (Hansen and Tarp (2000) referring to Rahman (1968), Weisskopf (1972), Griffin and Enos (1970) and Gupta (1970). A problem with these studies is that the endogeneity of aid is not addressed and the role of physical capital accumulation in the growth process is overemphasized. More recent evidence shows aid has a negative impact on domestic savings because of substitution (Nowak-Lehmann et al., 2012). In line with this, Boone (1996) finds that aid does not significantly increase investment, but it does increase consumption and expands the public sector. Mosley (1987) adds that aid can also change the structure of 
government spending depending on the government's preferences for consumption and investment.

The third generation of aid effectiveness studies addresses the aggregate effect of aid, namely, its direct impact on per capita income or its growth using the neoclassical Solow growth model (Doucouliagos and Paldam, 2009). The econometric techniques became more sophisticated and more scrutiny was placed on the country context of the aid recipient. Studies found diminishing returns to aid (Hansen and Tarp, 2001) and aid effectiveness to be dependent on features of the recipient countries such as good economic policy (Burnside and Dollar, 2000), the share of a country's area that lies in the tropics (Dalgaard et al., 2004), it is level of democratization (Svensson, 1999), institutional quality (Burnside and Dollar, 2004), political stability (Chauvet and Guillaumont, 2004), vulnerability to external shocks (Guillaumont and Chauvet, 2001), absorptive capacity (Chauvet and Guillaumont, 2004) and its national debt (Bjerg et al., 2011). All in all, the third-generation studies have produced mixed results. Some studies found a positive and significant impact of aid (Arndt et al., 2015), others found an insignificant impact (Burnside and Dollar, 2000; Easterly et al., 2004; Rajan and Subramanian, 2008; Doucouliagos and Paldam, 2009, 2011, 2013; Tezanos et al., 2013) and some studies even found a negative and significant impact of aid when institutional quality is low (Bräutigam and Knack, 2004). The third generation studies that analyze aid's impact on growth essentially indicate that it may be more insightful to focus on specific transmission channels of aid such as the impact of aid on investment, domestic savings, human capital, productivity or the real exchange rate.

The fourth generation of aid effectiveness studies moves away from studying the aggregate impact of aid to investigating the effectiveness of different types of aid (Rajan and Subramanian, 2008; Tezanos et al., 2013; Donaubauer et al., 2016).

Our study falls into the category of the macro analyzes of aid effectiveness examining the direct link between aid and investment and borrows aspects from the second-generation models by studying a specific channel of effectiveness, namely, the aid-investment nexus and from the third-generation models by treating aid as endogenous and considering geographic and environmental settings. Finally, we integrate approaches from the fourthgeneration models by examining the effectiveness of distinct types of aid.

It has to be pointed out that the varied outcomes of previous studies, from (significant) negative to (significant) positive aid coefficients, were sensitive to small changes in the data set, in the methodology and model specification (Easterly et al., 2004; Rajan and Subramanian, 2008; Doucouliagos and Paldam,2009; Roodman, 2007; Clemens et al., 2012). However, there are also research gaps that may explain the diverging regression results from previous studies and that we try to fill:

- not having sufficiently addressed econometric issues such as omitted variables bias; endogeneity and the estimation of spurious regressions; and

- the omission of settings in which aid unequivocally promotes investment.

In contrast to previous research, we aim to identify relevant investment drivers and relevant scenarios, in which aid can spur investment. To this end, we augment the investment model with various investment drivers that have been proposed in the literature. We then check the statistical significance of these potential drivers using the dynamic feasible generalized least squares (DFGLS) technique. After identifying statistically significant drivers of investment, we expose the regression model to various settings that have proven to be relevant, to capture discernible differences in aid effectiveness.

Additionally, we investigate whether unchangeable country characteristics such as geography, distance and historical past, are responsible for different responses to 
AEA

29,87

development aid. A further dimension we study is the aid amount in relation to a recipient country's GDP and check the aid-investment link in scenarios of high and low inflows of aid.

\section{The econometric model}

The standard [2] theoretical literature offers few and limited approaches (Keynesian and neoclassical; post-Keynesian and modern neoclassical) to explain investment behavior. The first is the Harrod-Domar/Samuelson accelerator model of investment. It states that increases in income accelerate capital accumulation and decreases accelerate capital depletion. Investment depends on the capital to output ratio and (expected) changes in income. Investment is determined by expectations for output growth and investor mood (Westerhoff, 2006). The second is the (modern) neoclassical approach (Fisher, 1930; Jorgenson, 1963) which puts less emphasis on expectations and risk but more emphasis on the user costs of capital that are mainly determined by the real interest rate, the relative price of capital and a depreciation allowance (Alexiou, 2009).

Both models have been subject to an empirical test by Alexiou (2009) but performed very poorly, pointing to the need to specify the investment environment more adequately.

We constructed a core model of investment (combining characteristics of both the accelerator and the neoclassical model), similar to Alexiou's, assuming that under wellfunctioning capital markets and rational decision-making, investment is determined by the profitability of investment, i.e. by the marginal product of capital, the real cost of capital and GDP growth. The real cost of capital is a function of the relative price of capital, the real interest rate, which also expresses the risk involved and the depreciation rate (Mankiw, 2009). Our analysis shows that the above-mentioned direct determinants of investment do not explain investment which is in line with the findings of Alexiou (2009) even though the empirical tests differed. We followed a cointegration approach, whereas Alexiou scrutinized the $t$-values of the above-mentioned direct investment determinants.

Together with Rama (1993), Chhibber and Dailami (1993), Dollar and Easterly (1999) and Agénor and Montiel (2008), we argue that other (indirect) investment determinants such as macroeconomic (i.e. debt-ratio, trade openness) and institutional environments should be included in an empirical investment model. This may be a more effective approach to model investment behavior given that the investment environment influences expectations. In terms of foreign aid, it should be treated as an international transfer of income if it is a grant. If it is a concessional loan (with a grant element of at least $25 \%$ ), however, it reduces the cost of capital and has a lower interest rate. To understand its impact on investment, we include foreign aid and its sub-components as separate explanatory variables and as direct investment determinants.

We use the underlying data (see online appendix [3]) to identify a systematic long-run relationship, i.e. cointegration, in the aid-investment nexus. To do so, we apply panel timeseries tests, which verify the existence of non-stationary series and stationary residuals (cointegration) in the investment models. We use gross fixed capital formation (the investment-to-GDP share) as a dependent variable, which captures overall investment at the national level but does not allow us to distinguish between domestic and foreign sources of investment. The results do not support the hypothesis that gross fixed capital formation is (exclusively) determined by the variables of the theoretical core model (real interest rate, risk, GDP growth). Hence, the determinants of investment in the core model are insufficient for explaining a long-lasting, systematic investment relationship in our sample of countries. In contrast, the variables of our extended investment model (aid, domestic savings, trade openness, etc.) seem to be systematically related to the investment-to-GDP ratio so that we use this model for our estimations. 
We proxy investment, our dependent variable, by gross capital formation as a share of GDP, which is comprising items such as machinery, plants and office buildings and inventory investment. Gross capital formation comes from both domestic and foreign sources.

Foreign aid as a driver of investment is the variable of interest measured by the net ODA as a ratio of GDP. Further, we use its composition, namely, grants or (net) loans, bilateral or multilateral aid. We also include aid spent on investment-related purposes to test whether aid can stimulate investment. Our expectation is that distinct types of foreign aid will vary in their effectiveness.

We also include the following macroeconomic variables: Domestic savings are essential for financing domestic investment and we expect to see a positive impact on investment (Ang, 2007; Feldstein and Horioka,1980; Narayan, 2005). An increase in external indebtedness is expected to have a negative impact on investment as amortization and interest payments reduce the financial means that could be used for investment (Alesina and Tabellini, 1989; Sachs, 1989; Savvides, 1992; Deshpande, 1997; Perkins et al., 2013). The openness of the economy also influences investment and we expect a positive impact. It indicates an extension of the market size which enables a higher degree of specialization and higher productivity (Alesina et al., 2005; Perkins et al., 2013; Dowrick and Golley, 2004). Greater economic growth is considered positive for investment by improving the investment environment and a positive sign is expected (Attanasio et al., 2000; Binder and Bröck, 2011).

These variables are included in the empirical investment model [4] as:

$$
i n v y_{i t}=\alpha_{i}+\beta \text { aidy }_{i t}+\gamma \text { domsy }_{i t}+\delta \text { debty }_{i t}+\varepsilon_{\text {tradey }}+\text { sgrowth }_{i t}+u_{i t}
$$

where the dependent variable, $i n v y_{i t}$ is the investment-to-GDP ratio in the country I at time $t$. aidy $y_{i t}$ denotes the aid-to-GDP ratio. domsy $y_{i t}$ is the domestic savings-to-GDP ratio, debty $y_{i t}$ is the external debt stock-to-GNI ratio and tradey $_{i t}$ is the sum of imports and exports divided by GDP, which denotes the trade openness of a country. growth rit $_{\text {represents economic }}$ growth measured as the annual change of GDP. $u_{i t}$ is the error term that is iid with mean zero and follows an I (0) process. $\alpha_{i}$ are country-fixed effects. $\beta$ is the coefficient of interest, which depicts the average effect (in our sample of countries) of a one-unit increase of the aidto-GDP ratio (or its subcomponents) on the investment-to-GDP ratio. All increases are in terms of percentage points. $\gamma, \delta, \varepsilon$ and $s$ indicate the impact of an increase in the domestic savings ratio, external indebtedness, trade openness and economic growth, respectively.

We find empirical evidence that, on average, aid, domestic savings, trade openness, external debt, GDP growth, institutions and to a lesser degree, TFP, are significant determinants of investment and could serve as relevant investment settings. Thus, we test our investment model in high and low settings of trade openness, institutional quality, GDP growth, TFP performance and external indebtedness, respectively.

Given the econometric limitations in previous studies on the aid-investment link, we propose applying time series and cointegration tests before running regressions. We complement the dynamic ordinary least squares (DOLS) or "leads and lags" approach, to control for all types of endogeneity (Wooldridge, 2009; Stock and Watson, 2012; Herzer and Grimm, 2012) using internal instruments, with an FGLS procedure to mitigate the omitted variable problem (Kmenta, 1986; Mukherjee et al., 1998; Greene, 2000). As such, suggesting the combined estimation procedure Dynamic FGLS (DFGLS), we avoid spurious regressions and biased regression coefficients. Omitted variable bias is mitigated by a Prais-Winsten transformation of the series (an FGLS procedure). 
AEA

29,87

196

We control for the endogeneity of all right-hand side variables by applying the DOLS approach (Wooldridge, 2009) as follows:

$$
\begin{aligned}
\text { invy }_{i t}= & \alpha_{i}+\beta \text { aidy }_{i t}+\gamma \text { domsy }_{i t}+\delta \text { tradey }_{i t}+\varepsilon \text { debty }_{i t}+\ldots+\text { sgrowth }_{i t} \\
& +\sum_{\mathrm{p}=-1}^{\mathrm{p}=+1} \mathrm{~b}_{\mathrm{p}} \Delta a i d y_{i t-\mathrm{p}}+\sum_{\mathrm{p}=-1}^{\mathrm{p}=+1} \mathrm{c}_{\mathrm{p}} \Delta d o m s y_{\mathrm{it}-\mathrm{p}}+\ldots+\sum_{\mathrm{p}=-1}^{\mathrm{p}=+1} \mathrm{~g}_{\mathrm{p}} \Delta \text { growth }_{i t-p} \\
& +v_{i t}
\end{aligned}
$$

DOLS removes the endogeneity by moving the endogenous parts of the regressors into the error term $\mathrm{u}_{\mathrm{it}}$ which takes the following form:

$$
u_{i t}=\sum_{\mathrm{p}=-1}^{\mathrm{p}=+1} \mathrm{~b}_{\mathrm{p}} \Delta a i d y_{i t-\mathrm{p}}+\sum_{\mathrm{p}=-1}^{\mathrm{p}=+1} \mathrm{c}_{\mathrm{p}} \Delta d o m s y_{\mathrm{it}-\mathrm{p}}+\ldots+\sum_{\mathrm{p}=-1}^{\mathrm{p}=+1} \mathrm{~g}_{\mathrm{p}} \Delta \text { growth }_{i t-p}+v_{i t}
$$

where $v_{i t}$ is uncorrelated with each change in the right-hand side variables by construction.

\section{Results}

\subsection{Is aid a determinant of investment?}

We estimate the relationship between aid and investment using equation (1) by applying the DFGLS technique as described in Section 3. Within the DFGLS technique, we incorporate country-fixed effects, control for endogeneity, autocorrelation and take heteroscedasticity and cross-country correlation of the residuals into account. Regressions in this section are based on either a simple (115 countries) or an extended/augmented investment model (91 countries). The data covers the period 1973-2011 and 1985-2011 if the institutional quality is included.

Based on a model which emphasizes the average impact of aid on investment, we find that aid has a positive and significant impact on investment and that all other regression coefficients carry the expected signs.

Comparing the aid coefficient produced with the DFGLS technique (Table 1, col. 1) with the aid coefficient produced with the DOLS technique (col. 2) results in similar aid coefficients of 0.30 and 0.35 , respectively. The DFGLS technique is preferable as it controls for omitted variable bias whereas the DOLS technique does not.

Considering the DFGLS estimations in col. 1 of Table 1, a 1 percentage point increase of the aid ratio increases the investment ratio by 0.30 percentage points. Looking at the mean values, an increase in the aid ratio from $3.8 \%$ to $4.8 \%$, which represents a $26 \%$ increase, will, therefore, equate to an increase in the investment ratio from $22.8 \%$ to $23.1 \%$ (this constitutes an increase of $1.3 \%$ ).

Based on results from the preferable DFGLS estimation technique, an increase of the domestic savings ratio by 1 unit increases the investment ratio by 0.34 units; if domestic savings increase from $15.2 \%$ to $16.2 \%$, which represents an increase of about $7 \%$, the investment ratio will increase from $22.8 \%$ to $23.1 \%$, which is about $1.5 \%$. These changes imply that domestic savings are more effective in raising investment than aid.

Trade openness has a positive and statistically significant influence on investment. A one percentage point increase of openness leads to an increase of the investment ratio by 0.12 percentage points. Furthermore, an increase of growth by one percentage point spurs investment by 0.37 units, increasing the investment ratio from an average of 22.8 to 23.2 


\begin{tabular}{lccc}
\hline & $(1)$ & $(2)$ & \\
Dependent variable: Investment/GDP & DFGLS & Aid spurs \\
investment
\end{tabular}

percentage points. In contrast, external indebtedness has a negative and non-significant although small - impact on investment confirming the burden of the debt service.

Computing the amount of investment generated by aid based on the aid coefficient in col. 1 of Table 1, we find that 1 dollar spent on aid translates into an increase in investment of about $\$ 1.70$ indicating the existence of forwarding and backward linkages of investment projects [5].

To guarantee the reliability of the regression coefficients presented in Table 1, we check for robustness by inserting non-linearities and by extending the model.

\subsection{The impact of aid on investment in different country groupings}

We also analyze the aid-investment relationship in different regions of the world (Africa, sub-Saharan Africa (SSA), North Africa, the Middle East, Latin America and Asia), by applying the extended investment model. We run the model with aid, domestic savings, external debt, trade openness and growth as right-hand side variables applying the DFGLS technique. The results are presented in Table 2 and we concentrate on the aid coefficients and the amount of investment that is generated by one dollar of aid.

We find that the aid coefficients for Africa, SSA, North Africa and the Middle East (Table 2, col. 1-4) are positive and statistically significant, whereas in Latin America and Asia (col. 5 and 6) they are not statistically different from zero. It is worth noting that Latin America and Asia have aid-to-GDP ratios (between 1.32 and 1.98\%), that are below the median (2\% aid-to-GDP ratio) and well below the mean (3.8\% aid-to-GDP ratio). Africa, SSA, North Africa and the Middle East, in contrast, have above-median aid-to-GDP values $(6.2 \%, 6.3 \%, 3.2 \%$ and $2.8 \%)$.

We also compute the amount of investment generated by one dollar of aid in Africa, SSA, North Africa and the Middle East. We find low values of $\$ 0.98$ and $\$ 0.27$ for Africa as a whole 
AEA

29,87

198

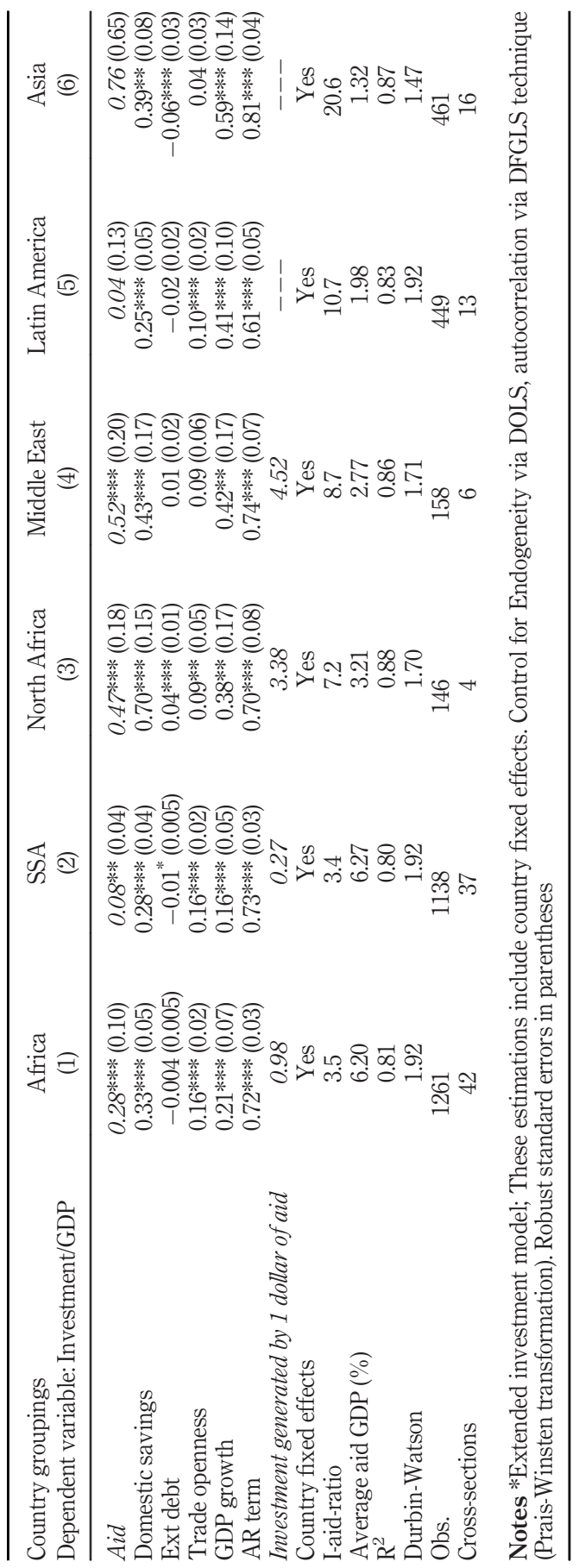

Table 2.

Aid effectiveness in different regions of the world* 
and SSA, respectively, high values of $\$ 3.38$ and $\$ 4.52$ for North Africa and the Middle East, indicating that here more investment is generated through backward and forward linkages.

\subsection{Is aid more favorable for investment in certain environments?}

For this analysis, we include environmental factors which are constant over time and determined by nature (climate, geography and being land-locked) or by history (e.g. colonial history). These factors are reflected in time-invariant country characteristics and are not attributable to policy interventions. Other environments are set by time-variant factors as institutional quality, aid ratio and economic growth.

The environmental effect is modeled by the inclusion of country-specific fixed effects. When working with country fixed effects, the average intercept and the deviation from the intercept for each country are used to split the sample into countries with a below-average intercept (signaling unfavorable conditions/country characteristics) and above-average intercepts (signaling favorable conditions/country characteristics). A below-average intercept implies a below-average autonomous investment [6] and an above-average intercept implies an aboveaverage autonomous investment.

Table 3 (columns 1 and 2) provides evidence that an increase in the aid-to-GDP ratio leads to a significant increase in the investment-to-GDP ratio in countries that enjoy favorable country characteristics, whereas it is non-significant in countries with an unfavorable environment.

Interestingly, other variables such as increased domestic savings and trade openness enhance investment to a greater extent under favorable country conditions than under unfavorable country conditions. Table 3 (columns 3 and 4 ) shows the effect of aid on investment in high and low institutional settings. In column 3, we see that aid promotes investment when institutional quality is high. This is in line with the statement above on the importance of good institutions for investment. The rule of law, low levels of corruption and high bureaucratic quality can increase the investment share in recipient countries.

Moreover, we investigate the impact of an environment of disproportionately high or low amounts of aid in relation to a recipient country's GDP. Hence, in Table 3, columns 5 and 6 , we test whether the effectiveness of aid is higher in countries that receive aid payments above the median compared to countries that receive aid amounts below the median. We find that in countries receiving above-median amounts of aid (more than $2 \%$ ), aid is always effective. There is also some vague evidence (confidence of $90 \%$ ) that a one percentage point increase of the aid-to-GDP ratio in below-median aid receiving countries generates about twice as much investment as a one percentage point increase in the aid ratio in abovemedian aid recipients. Furthermore, in environments with relatively high amounts of aid, the effectiveness of trade openness is higher and the effectiveness of domestic savings is a bit lower.

Finally, we analyze the impact of high or low GDP growth (col. 7 and 8) on the effectiveness of aid. We find that aid enhances an investment in economies that grow above the average rate $(4.1 \%$; median values with $4.2 \%$ are almost the same) but not in countries that grow below the average rate. Domestic savings and trade openness seems to have a greater impact on investment in poor growth environments, and therefore, slightly compensate for the low growth environment.

To conclude, aid does not spur investment when countries face unfavorable conditions and suffer from low institutional quality. It seems that path dependency and low-level economic equilibria have an effect on investment spending and historical past influences the quality of institutions and administrative structures, which provide the basis and security for investment decisions. In contrast, aid is always effective at increasing investment when 
AEA

29,87

200

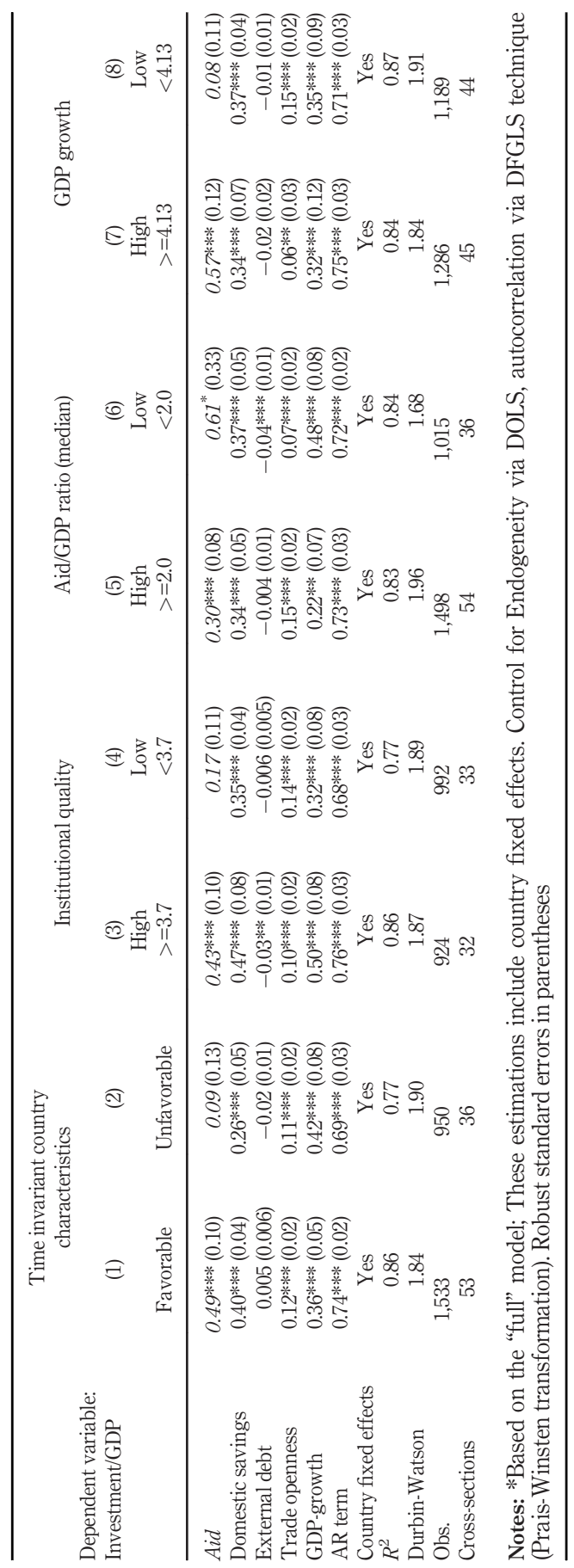

Table 3.

Aid effectiveness under different environments ${ }^{*}$ 
the relative amount of aid is increased. This holds for settings with relatively high and low starting levels of aid.

\subsection{Are certain types of aid more investment-promoting than others?}

We now turn to the role of different aid categories in promoting investment, as it is reasonable to assume that distinct types of aid differ in their impact on investment. What we see in Table 4 columns 1 to 6 is that domestic savings and trade openness contribute positively to investment and are statistically significant. For grants and net loans (col. 2) and aid to improve institutions (col. 6), no significant effects can be found, but the rest of the aid categories (columns 1, 3, 4 and 5) seem to have a statistically significant impact on the investment ratio.

The sub-types of aid, bilateral and multilateral aid (col. 1), do influence investment in a significant way. Unsurprisingly, investment-related aid (col. 3) has a significant influence on investment in addition to non-investment targeting aid. Backward and forward linkages in production and investment can possibly explain this phenomenon.

In particular, aid used for infrastructure (col. 4) and its sub-component communications (col. 5 ), is very effective at boosting investment. However, its impact is not as large as the figure of 4.23/3.94 seems to suggest. These numbers imply that if aid is increased by about 100 times (which is unrealistic), then the investment ratio would rise by about 4 units (percentage points). In contrast, aid targeted at institutions (col. 6) has a non-significant impact. This could imply that investing in institutional improvement does not need much physical investment but rather an improvement in quality, which most often requires a change in habits, attitudes and priorities. It does not imply that aid targeted at institutional quality is ineffective.

\section{Conclusion}

This study sheds light on the aid-investment link. Apart from very heterogeneous and country-specific aid-investment relations, we discovered some generalizable aid-investment linkages. On the one hand, aid spurs investment, but factors such as domestic savings and economic growth are equally important. When countries enjoy favorable (time-invariant) conditions, have good institutions or receive above-median aid-to-GDP ratios (higher than $2 \%$ ), aid promotes investment significantly.

The amount of investment that is generated by one dollar of aid is low in Africa as a whole, especially in sub-Saharan Africa. In these regions, linkage effects of investment seem to be lower than in North Africa and the Middle East. Differentiating between the subcomponents of aid revealed that the general, quite stable positive impact of aid on investment is driven by both bilateral and multilateral aid while the latter is more effective in promoting investment. Interestingly, we find that both investment-related and noninvestment-related aid (targeting the health and education sectors) are effective in promoting investment as well. There is evidence that aid for infrastructure spurs investment. No investment-enhancing effect could be found for aid allocated for the improvement of institutions. However, even if aid given to improve institutions does not increase investment directly, it might do indirectly, if it succeeds in enhancing the institutional quality. As such, our empirical evidence suggests development aid should be given in sizable amounts exceeding a $2 \%$ share of a recipient country's GDP.

One limitation of our study can also give scope for further research: The main variable of interest is gross fixed capital formation (the investment-to-GDP share) which is an aggregate of domestic and foreign shares in the national investment. It would be interesting 
AEA

29,87

202



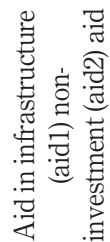





(6)

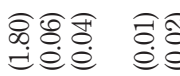





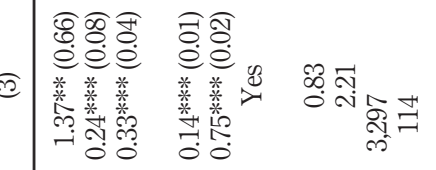

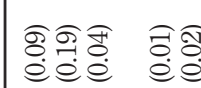

ชิ



瓷



巡

离

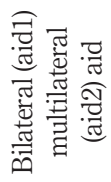

Table 4

Effectiveness of

different types of aid 宅

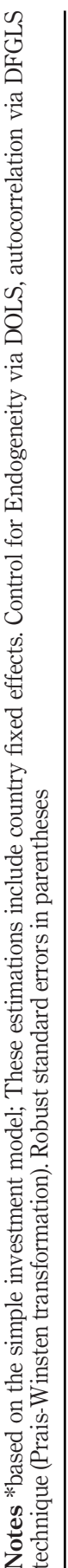


to see whether and how development aid or different types thereof, promote domestically financed and foreign investment.

The G20 Compact with Africa as a political agenda aims to increase investment relations between private investors of industrialized countries and developing nations. The initiative should, however, not disregard that development aid itself is a contributor to investment in developing countries and fulfills its purpose if country conditions are favorable in terms of geography and institutions and if development aid is given in sufficient quantities.

\section{Notes}

1. The overall supply of savings (total savings) is increased through the aid inflow, thus lowering the rate of interest, and hence the incentive to save.

2. According to non-standard models, investment in developing countries might be characterized by the decision-making processes such as those described by Thaler (1994) and Kahneman (2013) which include irrational behavior.

3. The online appendix [http://www2.vwl.wiso.uni-goettingen.de/RePEc/index.php?ser_id=7; search Nowak-Lehmann]includes Tables reporting a list of countries (A1), data sources (A2), descriptive statistics (A3), statistical test (A4 and A5), countries by aid effectiveness (A6 and A7), stepwise regression procedure (A8, A9, A10).

4 Dollar and Easterly (1999) start out with a basic aid-investment model and augment it by policy variables.

5 This is not to be confused with the return on aid in terms of generated income as computed by Dalgaard and Hansen (2015). These authors found annual rates of return for aid on investment of about $20 \%$.

6 Autonomous investment is the minimum investment required holding other investment determinants constant.

\section{References}

Agénor, P.R. and Montiel, P.J. (2008), Development Macroeconomics, Princeton University Press, Princeton, NJ.

Alesina, A. and Tabellini, G. (1989), "External debt, capital flight and political risk", Journal of International Economics, Vol. 27 Nos 3/4, pp. 199-220.

Alesina, A., Spolaore, E. and Wacziarg, R. (2005), “Chapter 23: trade, growth and the size of countries”, in Aghion P. and Durlauf, S.N. (Eds), Handbook of Economic Growth, Elsevier North Holland, Amsterdam, The Netherlands.

Alexiou, C. (2009), "Modelling investment behaviour: emerging evidence", The Indian Economic Journal, Vol. 56 No. 4, pp. 21-36.

Alvi, E. and Senbeta, A. (2012), "Foreign aid: good for investment, bad for productivity", Oxford Development Studies, Vol. 40 No. 2, pp. 139-161.

Ang, J.B. (2007), “Are saving and investment cointegrated? The case of Malaysia (1965-2003)”, Applied Economics, Vol. 39 No. 17, pp. 2167-2174.

Arazmuradov, A. (2012), "Foreign aid, foreign direct investment and domestic investment nexus in landlocked economies of Central Asia”, MPRA Paper No. 36958. University of Munich.

Arndt, C., Jones, S. and Tarp, F. (2010), “Aid, growth, and development: have we come full circle?”, Journal of Globalization and Development, Vol. 1 No. 2, pp. 1-27. 
AEA 29,87

Arndt, C., Jones, S. and Tarp, F. (2015), “Assessing foreign aid"s long run contribution to growth and development", World Development, Vol. 69, pp. 6-18.

Arndt, C., Jones, S. and Tarp, F. (2016), "What is the aggregate economic rate of return to foreign aid?", The World Bank Economic Review, Vol. 30 No. 3, pp. 446-474.

Attanasio, O.P., Picci, L. and Scorcu, A.E. (2000), "Saving, growth, and investment: a macroeconomic analysis using a panel of countries", Review of Economics and Statistics, Vol. 82 No. 2, pp. 182-211.

Binder, M. and Bröck, S. (2011), "Chapter 4: on the relation between investment and economic growth: new cross-country empirical evidence", in de La Grandville, O. (Ed.), Economic Growth and Development, Emerald Group Publishing Limited, Bingley.

Bjerg, C., Bjørnskov, C. and Holm, A. (2011), "Growth, debt burdens and alleviating effects of foreign aid in least developed countries", European Journal of Political Economy, Vol. 27 No. 1, pp. 143-153.

Boone, P. (1996), "Politics and the effectiveness of foreign aid", European Economic Review, Vol. 40 No. 2, pp. 289-329.

Bowles, P. (1987), "Foreign aid and domestic savings in less developed countries: some tests for causality", World Development, Vol. 15 No. 6, pp. 789-796.

Bräutigam, D.A. and Knack, S. (2004), "Foreign aid, institutions, and governance in Sub-Saharan Africa", Economic Development and Cultural Change, Vol. 52 No. 2, pp. 255-285.

Burnside, C. and Dollar, D. (2004), "Aid, policies, and growth: revisiting the evidence”, Policy Research Working Paper Series 3251, World Bank, Washington, DC.

Burnside, C. and Dollar, D. (2000), “Aid, policies, and growth”, American Economic Review, Vol. 90 No. 4, pp. 847-868.

Chauvet, L. and Guillaumont, P. (2004), "Aid and growth revisited: policy, economic vulnerability, and political instability”, in Tungodden, B., Stern, N. and Kolstad, I. (Eds), Toward Pro-Poor Policies. Aid, Institutions, and Globalization, World Bank and Oxford University Press, Washington, DC and New York, NY, pp. 95-109.

Chenery, H.B. and Strout, A.M. (1966), "Foreign assistance and economic development", American Economic Review, Vol. 56 No. 4, pp. 679-733.

Chhibber, A. and Dailami, M. (1993), "Fiscal policy and private investment in developing countries: recent evidence on key selected issues", in Faini, R. and de Melo, J. (Eds), Fiscal Issues in Adjustment in Developing Countries, Palgrave Macmillan, London.

Clemens, M.A., Radelet, S., Bhavnani, R.R. and Bazzi, S. (2012), "Counting chickens when they hatch", The Economic Journal, Vol. 122 No. 561, pp. 590-617.

Dalgaard, C.J. and Hansen, H. (2015), “The return to foreign aid”, WIDER Working Paper No. 2015/053. United Nations University (UNU) and World Institute for Development Economics Research (WIDER).

Dalgaard, C.J., Hansen, H. and Tarp, F. (2004), “On the empirics of foreign aid and growth”, Economic Journal, Vol. 114 No. 496, pp. 191-216.

Deshpande, A. (1997), "The debt overhang and the disincentive to invest", Journal of Development Economics, Vol. 52 No. 1, pp. 169-187.

Dollar, D. and Easterly, W. (1999), "The search for the key: aid, investment and policies in Africa", Journal of African Economies, Vol. 8 No. 4, pp. 546-577.

Donaubauer, J., Meyer, B. and Nunnenkamp, P. (2016), "Aid, infrastructure, and FDI: assessing the transmission channel with a new index of infrastructure", World Development, Vol. 78, pp. 230-245.

Doucouliagos, H. and Paldam, M. (2006), “Aid effectiveness on accumulation: a meta study”, Kyklos, Vol. 59 No. 2, pp. 227-254. 
Doucouliagos, H. and Paldam, M. (2009), "The aid effectiveness literature: the sad results of 40 years of research", Journal of Economic Surveys, Vol. 23 No. 3, pp. 433-461.

Dowrick, S. and Golley, J. (2004), "Trade openness and growth: who benefits?", Oxford Review of Economic Policy, Vol. 20 No. 1, pp. 38-56.

Easterly, W., Levine, R. and Roodman, D. (2004), “Aid, policies, and growth: comment”, American Economic Review, Vol. 94 No. 3, pp. 774-780.

Feldstein, M. and Horioka, C. (1980), "Domestic savings and international capital flows", The Economic Journal, Vol. 90 No. 358, pp. 314-329.

Fisher, I. (1930), The Theory of Interest, Macmillan, New York, NY.

Garriga, A.C. and Phillips, B.J. (2014), "Foreign aid as a signal to investors: predicting FDI in postconflict countries", Journal of Conflict Resolution, Vol. 58 No. 2, pp. 280-306.

Gomanee, K., Girma, S. and Morrissey, O. (2005), "Aid and growth in Sub-Saharan Africa: accounting for transmission mechanisms", Journal of International Development, Vol. 17 No. 8, pp. 1055-1075.

Greene, W.H. (2000), Econometric Analysis, 4th ed., Prentice-Hall International (UK) Limited, London.

Griffin, K.B. and Enos, J.L. (1970), "Foreign assistance. Objectives and consequences", Economic Development and Cultural Change, Vol. 18 No. 3, pp. 313-327.

Guillaumont, P. and Chauvet, L. (2001), “Aid and performance: a reassessment”, Journal of Development Studies, Vol. 37 No. 6, pp. 66-92.

Gupta, K.L. (1970), "Foreign capital and domestic savings: a test of Haavelmo's hypothesis with cross-country data: a comment", The Review of Economics and Statistics, Vol. 52 No. 2, pp. 214-216.

Hansen, H. and Tarp, F. (2000), "Aid effectiveness disputed”, Journal of International Development, Vol. 12 No. 3, pp. 375-398.

Hansen, H. and Tarp, F. (2001), "Aid and growth regressions", Journal of Development Economics, Vol. 64 No. 2, pp. 547-570.

Herzer, D. and Grimm, M. (2012), "Does foreign aid increase private investment? Evidence from panel cointegration", Applied Economics, Vol. 44 No. 20, pp. 2537-2550.

Jorgenson, D.W. (1963), "Capital theory and investment behaviour", American Economic Review, Vol. 53, pp. 247-259.

Kahneman, D. (2013), Thinking, Fast and Slow, Macmillan USA.

Kmenta, J. (1986), Elements of Econometrics, 2nd ed., MacMillan, New York, NY.

Levine, R. and Renelt, D. (1992), "A sensitivity analysis of cross-country growth regressions”, American Economic Review, Vol. 82, pp. 942-963.

Lucas, R.E., Jr(1990), "Why doesn"t capital flow from rich to poor countries", The American Economic Review, Vol. 80 No. 2, pp. 92-96.

Mankiw, N.G. (2009), Macroeconomics, 7th ed., Worth Publishers, New York, NY.

Mekasha, T.J. and Tarp, F. (2013), "Aid and growth: what meta analysis reveals", The Journal of Development Studies, Vol. 49 No. 4, pp. 564-583.

Mosley, P. (1987), "Aid, the public sector and the market in less developed countries", The Economic Journal, Vol. 97 No. 387, pp. 616-641.

Mukherjee, C., White, H. and Weyts, M. (1998), Econometrics and Data Analysis for Developing Countries, Routledge, London and New York, NY.

Narayan, P.K. (2005), "The saving and investment nexus for China: evidence from cointegration tests", Applied Economics, Vol. 37 No. 17, pp. 1979-1990. 
AEA 29,87

Nowak-Lehmann, F., Dreher, A., Herzer, D., Klasen, S. and Martinez-Zarzoso, I. (2012), "Does foreign aid really raise per capita income? A time series perspective", Canadian Journal of Economics/Revue Canadienne D'économique, Vol. 45 No. 1, pp. 288-313.

Perkins, D.H., Radelet, S., Lindauer, D.L. and Block, S.A. (2013), Economics of Development, W. W. Norton and Company, New York, NY.

Rahman, M.A. (1968), "Foreign capital and domestic savings: a test of Haavelmo's hypothesis with Cross-Country data", The Review of Economics and Statistics, Vol. 50 No. 1, pp. 137-138.

Rajan, R.G. and Subramanian, A. (2008), "Aid and growth: what does the cross-country evidence really show?", Review of Economics and Statistics XC, Vol. 90 No. 4, pp. 643-665.

Rajan, R.G. and Subramanian, A. (2011), “Aid, dutch disease, and manufacturing growth”, Journal of Development Economics, Vol. 94 No. 1, pp. 106-118.

Rama, M. (1993), "Empirical investment equations in developing countries", in Servén, L. and Solimano, A. (Eds), Striving for Growth after Adjustment, World Bank, Washington, DC.

Romer, P.M. (1986), "Increasing returns and long-run growth", Journal of Political Economy, Vol. 94 No. 5, pp. 1002-1037.

Roodman, D. (2007), "Macro aid effectiveness research: a guide for the perplexed", Working Paper Number 134 Center for Global Development, Washington, DC.

Rosenstein-Rodan, P.N. (1961), "Notes on the theory of the "big push", Economic Development for Latin America, pp. 57-81.

Sachs, J. (1989), "The debt overhang of developing countries”, in Calvo, G.A., Findlay, R., Kouri, P. and Macedo, J.B. (Eds), Debt, Stabilization and Development, Basil Blackwell, Oxford.

Savvides, A. (1992), "Investment slowdown in developing countries during the 1980s: debt overhang or foreign capital inflows?", Kyklos, Vol. 45 No. 3, pp. 363-378.

Selaya, P. and Rytter Sunesen, E. (2012), "Does foreign aid increase foreign direct investment?", World Development, Vol. 40 No. 11, pp. 2155-2176.

Solow, R. (1956), "A contribution to the theory of economic growth", The Quarterly Journal of Economics, Vol. 70 No. 1, pp. 65-94.

Stock, J.H. and Watson, M.W. (2012), Introduction to Econometrics, Addison Wesley, Boston.

Svensson, J. (1999), "Aid, growth and democracy", Economics and Politics, Vol. 11 No. 3, pp. 275-297.

Swan, T.W. (1956), "Economic growth and capital accumulation”, Economic Record, Vol. 32 No. 2, pp. 334-361.

Thaler, R. (1994), Quasi Rational Economics, Russell Sage Foundation.

Weisskopf, T.E. (1972), "The impact of foreign capital inflow on domestic savings in underdeveloped countries", Journal of International Economics, Vol. 2 No. 1, pp. 25-38.

Westerhoff, F.H. (2006), "Samuelson's multiplier-accelerator model revisited", Applied Economics Letters, Vol. 13 No. 2, pp. 89-92.

Wooldridge, J.M. (2009), Introductory Econometrics: A Modern Approach, OH, South-Western Cengage Learning, Mason.

\section{Further reading}

Harrod, R.F. (1939), "An essay in dynamic theory", The Economic Journal, Vol. 49 No. 193, pp. 14-33.

International Country Risk Guide (2011), The PRS Group, East Syracuse New York, NY. Data on Institutional Quality. 
Penn World Tables (PWT version 9), available at: www.rug.nl/ggdc/productivity/pwt (accessed 28 March 2017).

Tierney, M.J., Nielson, D.L., Hawkins, D.G., Roberts, J.T., Findley, M.G. and Powers, R.M. (2011), "More dollars than sense: refining our knowledge of development finance using aid data", World Development, Vol. 39 No. 11, pp. 1891-1906.

World Development Indicators (2016), The World Bank, Washington, DC, D.C, available at: http://databank.worldbank.org/data/reports.aspx?source=world-development-indicators

\section{Corresponding author}

Felicitas Nowak-Lehmann can be contacted at:fnowak@gwdg.de

For instructions on how to order reprints of this article, please visit our website: 